Original Article

\title{
BIOEQUIVALENCE STUDIES OF MARKETED CLOZAPINE TABLETS BY USING OPTIMIZED VALIDATED LIQUID CHROMATOGRAPHIC METHOD
}

\author{
UDAYASREE KONIKURU*, RAJAVEL P., VIJITHA S. \\ Department of Pharmaceutical Analysis, Sree Vidyanikethan College of Pharmacy, Sree Sainath Nagar, A. Rangampet, Tirupati, Chittoor \\ (Dist.), A. P. \\ Email: udayasreekonikuru@gmail.com
}

Received: 21 Jan 2018, Revised and Accepted: 08 Apr 2018

\begin{abstract}
Objective: A simple, selective, precise and accurate method was developed for the estimation of Clozapine by RP-HPLC technique.

Methods: Chromatographic conditions used are stationary phase, Phenomenex BDS (150 mm x $4.6 \mathrm{~mm}, 5 \mu)$, Mobile phase was methanol and water in $(80: 20)$ ratio and flow rate was maintained at $1.0 \mathrm{ml} / \mathrm{min}$, column temperature was set at $25^{\circ} \mathrm{C}$, detection wavelength was $240 \mathrm{~nm}$, and diluent was mobile phase. These conditions were finalized for the optimized method.

Results: Linearity study was carried out between $10-60 \mu \mathrm{g} / \mathrm{ml}$, the $\mathrm{R}^{2}$ value was found to be as 0.995 . Precision was found to be as follows for system precision 1.052, method precision 1.662, and intraday precision 1.02 and for interday precision 0.93 . The \% Recovery was found to be $98.60 \%$. LOD and LOQ were found to be $2.7 \mu \mathrm{g} / \mathrm{ml}$ and $8.4 \mu \mathrm{g} / \mathrm{ml}$ respectively. By using the above method assay of the marketed formulation was carried out and the \% purity was found to be $99.28 \%$. Stability studies of Clozapine were done, in all conditions degradation was found to be within the acceptable range.
\end{abstract}

Conclusion: The current validated method was finally applied in bioequivalence studies of four different brands of Clozapine by using dissolution apparatus and percentage drug release was found to be $99.48 \%$, it was within the acceptable limit (NLT $85 \%$ ) as per USP.

Keywords: Clozapine, RP-HPLC, Degradation, Bioequivalence

(C) 2018 The Authors. Published by Innovare Academic Sciences Pvt Ltd. This is an open access article under the CC BY license (http://creativecommons.org/licenses/by/4.0/) DOI: http://dx.doi.org/10.22159/ijcpr.2018v10i3.27337

\section{INTRODUCTION}

Clozapine is a tricyclic benzodiazepine, classified as an atypical antipsychotic agent. It binds several types of central nervous system receptors and displays a unique pharmacological profile. Clozapine is a serotonin antagonist, with strong binding to $5-\mathrm{HT} 2 \mathrm{~A} / 2 \mathrm{C}$ receptor subtype. It also displays a strong affinity to several dopaminergic receptors but shows only weak antagonism at the dopamine D2 receptor, a receptor commonly thought to modulate neuroleptic activity. Agranulocytosis is a major adverse effect associated with the administration of this agent [1]. (fig. 1)

Extensive literature survey revealed that a few HPLC $[2,3]$ and bioanalytical [4-6] methods have been reported for quantitative estimation of clozapine in pharmaceutical formulations and biological fluids, which include Spectrophotometric, and bioanalytical methods. Current research work was mainly to develop a simple, rapid, precise, accurate and reproducible isocratic RP-HPLC method for the determination of clozapine and the developed method is validated with respect to specificity, linearity, precision, accuracy, range, LOD, LOQ, robustness, ruggedness, stability and bioequivalence studies. The method validated in accordance with International Conference on Harmonization (ICH) guidelines.

\section{MATERIALS AND METHODS}

\section{Standard drugs}

Clozapine was procured from the Arvind Remedies Pvt Ltd, Chennai.

\section{Chemicals and reagents}

HPLC Grade Methanol (Merck), HPLC Grade Water (Merck and Rankem).

\section{Instruments}

HPLC (SHIMADZU-SPD), UV (Agilent Technologies, Cary 60 Uv-Vis), Detector (UV detector), Column (Phenomenex ODS $\mathrm{C}_{18},(150 \times 4.6$ $\mathrm{mm}, 5 \mu$ ), Software (Spinchrome), Ultra-Sonicator (Tharmo LabCleaner).

\section{Preparation of mobile phase}

Accurately measured $800 \mathrm{ml}$ of Methanol(HPLC grade) mixed with $200 \mathrm{ml}$ of Water (HPLC grade) was degassed in an ultrasonicator for $10 \mathrm{~min}$ and then filtered through $0.45 \mu$ filter under vacuum filtration. The mobile phase was used as diluent.

\section{Standard preparation}

Accurately weighed $50 \mathrm{mg}$ of Clozapine was transferred into $50 \mathrm{ml}$ $\mathrm{V} . \mathrm{F}$ and final volume was made with diluent to get $1000 \mu \mathrm{g} / \mathrm{ml} .1 \mathrm{ml}$ of above solution was pipetted into $10 \mathrm{ml} \mathrm{V}$. F and volume was made with diluent to get $100 \mu \mathrm{g} / \mathrm{ml}$. From the above solution, $1 \mathrm{ml}$ was transferred into $10 \mathrm{ml} \mathrm{V.F}$ and final volume was diluted to obtain 10 $\mu \mathrm{g} / \mathrm{ml}$ and injected into HPLC (fig. 4)

\section{Selection of wavelength $(\lambda \max )$}

Standard solution of $10 \mu \mathrm{g} / \mathrm{ml}$ Clozapine was prepared and scanned in the UV-Visible spectrophotometer in the range of 200 to $400 \mathrm{~nm}$ by using methanol and water $(80: 20 \mathrm{v} / \mathrm{v})$ as blank to determine $\lambda \max ($ fig. 2)

\section{Quantitative determination of clozapine}

Preparation of sample solution

20 tablets of Clozapine were weighed and finely powdered. An accurately weighed quantity of powder equivalent to $50 \mathrm{mg}$ of clozapine was taken in a $50 \mathrm{ml} \mathrm{V.F}$ and $25 \mathrm{ml}$ of diluent was added. The flask was sonicated for $10 \mathrm{~min}$ and final volume was made with diluent to get $1000 \mu \mathrm{g} / \mathrm{ml}$. From this further dilution was made to get a final concentration of $10 \mu \mathrm{g} / \mathrm{ml}$. The percentage purity of drug present in the sample was calculated (fig. 5).

\section{Method development}

\section{Chromatographic conditions}

The column used was $\mathrm{aC}_{18}$ column $(150 \times 4.6 \mathrm{~mm}$, i.d., $5 \mu)$. The mobile phase consisted of a mixture of 80 volumes of methanol and 
20 volumes of water. The mobile phase was filtered through $0.45 \mu$ filter and degassed in ultrasonicator prior to use. Chromatography was performed at a temperature of $25{ }^{\circ} \mathrm{C}$ by pumping the mobile phase at a flow rate of $1.0 \mathrm{ml} / \mathrm{min}$. The analyte was monitored at a wavelength of $240 \mathrm{~nm}$ using UV-detector. The retention time of both standard and sample Clozapine was found to be 4.790. The optimized conditions are shown in table.1.

\section{Method validation}

The developed method was validated as per ICH guidelines for the following parameters [7].

\section{Specificity}

Specificity is the ability of the analytical method to measure accurately and specifically the analyte in the presence of components that may be expected to be present in the solution. The specificity of the method was determined by spiking the placebo at a specific level to standard drug solution $(10 \mu \mathrm{g} / \mathrm{ml})$. The blank, placebo and mixture of placebo and Clozapine solutions were injected to observe any interference with the drug peak.

\section{Linearity}

Linearity is the ability of the method to produce results that are directly proportional to the concentration of the analyte in samples with given range. The linearity of Clozapine was performed in the range of $10-60 \mu \mathrm{g} / \mathrm{ml}$. A calibration curve was plotted and regression coefficient was calculated (fig. 3)

\section{Accuracy}

Accuracy is the closeness of results obtained by a method to the true value. The accuracy of the method was evaluated by standard addition method. Recovery of the method was determined by spiking a known concentration the pure drug $(80,100,120 \%)$ at three different concentration levels to sample.

\section{Precision}

The precision of an analytical procedure expresses the closeness of agreement (degree of scattering) between a series of measurements obtained from multiple sampling of the same homogeneous sample under the prescribed conditions. It is expressed as standard deviation or relative standard deviation.

\section{System precision}

The standard solution of Clozapine $10 \mu \mathrm{g} / \mathrm{ml}$ was injected and measured the area for all injections in HPLC. The \% RSD for the area of replicate injections was found to be within the specified limits.

\section{Method precision}

The sample solution of Clozapine $10 \mu \mathrm{g} / \mathrm{ml}$ was injected and measured the area for all injections in HPLC. The \%RSD for the area of replicate injections was found to be within the specified limits.

\section{Intraday precision}

Intraday precision studies were performed by injecting a standard solution of $10 \mu \mathrm{g} / \mathrm{ml}$ at several intervals i.e., 1,3 and $5 \mathrm{~h}$ within a day.

\section{Interday precision}

The Interday precision was carried out for three days with $10 \mu \mathrm{g} / \mathrm{ml}$ Clozapine standard solutions.

\section{Limit of detection and limit of quantification}

Detection limit of an individual analytical procedure is the lowest amount of analyte in a sample which can be detected but not necessarily quantitated as an exact value and quantitation limit of an individual analytical procedure is the lowest amount of analyte in a sample which can be quantitatively determined with suitable precision and accuracy. LOD and LOQ of Clozapine were separately determined based on the standard deviation of the response of the respective calibration curve.

$\mathrm{LOD}=3.3 \times \sigma / \mathrm{s}$

$\mathrm{LOQ}=10 \times \sigma / \mathrm{s}$
Where $\sigma=$ Standard deviation

$\mathrm{S}=$ Slope

\section{Robustness}

The robustness of an analytical procedure is a measure of its capacity to remain unaffected by small, but deliberate variations in method parameters and provides an indication of its reliability during normal usage. The robustness of test method was demonstrated by carrying out Flow rate variation $\pm 0.1 \mathrm{ml}$, i.e. $(0.9 \mathrm{ml}$ and $1.1 \mathrm{ml} / \mathrm{min})$ and Wavelength variation $\pm 2 \mathrm{~nm}$ i.e. $(238 \mathrm{~nm}$ and $240 \mathrm{~nm})$.

\section{Ruggedness}

The ruggedness of analytical method is a degree of reproducibility of results obtained under a variety of conditions, such as different laboratories, analysts, instruments, environmental conditions, operators, and materials. Ruggedness studies were performed by analyzing the two sets of $10 \mu \mathrm{g} / \mathrm{ml}$ standard solutions of Clozapine prepared by two analysts under the same experimental conditions.

\section{System suitability}

System suitability is defined as "the checking of a system, before or during analysis of unknowns, to ensure system performance."A Standard solution of Clozapine $10 \mu \mathrm{g} / \mathrm{ml}$ was prepared and injected six times into HPLC. Then the system suitability parameters were evaluated from standard Chromatograms obtained by calculating the retention time, tailing factor, theoretical plates and peak areas from six replicate injections.

\section{Stability studies}

These studies are used to evaluate an analytical method's ability to measure an active ingredient and its degradation products without interference. Standard solution of Clozapine was exposed to $0.1 \mathrm{~N}$ $\mathrm{HCL}, 0.1 \mathrm{~N} \mathrm{NaOH}, 3 \% \mathrm{H}_{2} \mathrm{O}_{2}$, heat, UV-Light, and water. The degraded samples were analyzed using HPLC to determine if there are interferences with the standard. Thus, the stability-indicating property was evaluated [8-10].

\section{Bioequivalence studies}

It is a relative term which denotes that the drug substance in two or more identical dosage forms, reaches the systemic circulation at the same relative rate and to the same relative extent i.e. their plasma concentration-time profiles will be identical without significant difference.

\section{Preparation of acetate buffer (pH 4.0)}

Accurately weighed $2.2 \mathrm{gm}$ of sodium hydroxide pellets in $1000 \mathrm{ml}$ of V. F and about $900 \mathrm{ml}$ of distilled water was added and mixed. Then it was made up to the mark with distilled water. Then $\mathrm{pH}$ was adjusted to 4.0 with a glacial acetic acid solution.

\section{Preparation of clozapine standard drug solution}

$50 \mathrm{mg}$ of Clozapine standard was accurately weighed and transferred into a clean and dry $50 \mathrm{ml} \mathrm{V}$. F, dissolved in sufficient volume of acetate buffer and sonicated for $5 \mathrm{~min}$. The final volume made up to $50 \mathrm{ml}$ with acetate buffer $(1000 \mu \mathrm{g} / \mathrm{ml})$. From the above stock solution $1 \mathrm{ml}$ was pipetted out and transferred into $10 \mathrm{ml} \mathrm{V.F}$ and the remaining volume was made with mobile phase to get 100 $\mu \mathrm{g} / \mathrm{ml}$. From the above solution, $1 \mathrm{ml}$ was taken into $10 \mathrm{ml}$ volumetric flask and the final volume was made up to the mark with mobile phase $(10 \mu \mathrm{g} / \mathrm{ml})$ and injected into HPLC.

\section{Dissolution procedure}

$900 \mathrm{ml}$ of $\mathrm{pH} 4.0$ acetate buffer was added in each of the eight vessels of dissolution apparatus 2 (paddle). After reaching a temperature of $37^{\circ} \mathrm{C}$, four brands of clozapine tablets were added (two vessels for each brand). The machine was operated at the rotation of paddle speed at $100 \mathrm{rpm}$. After $45 \mathrm{~min}$, samples were withdrawn from the vessels and filtered through Whatman filter paper. From the filtrate, $4 \mathrm{ml}$ was transferred into $10 \mathrm{ml}$ volumetric flask and remaining volume was made with diluent. The final diluted sample solutions were filtered by using $0.45 \mu \mathrm{m}$ membrane filter 
and injected into HPLC. The amount of clozapine present in each formulation and its percentage of drug release was calculated by comparing with the standard.

\section{RESULTS AND DISCUSSION}

\section{Quantitative determination of clozapine}

The percentage purity of specified Clozapine formulation was found to be $99.28 \% \mathrm{w} / \mathrm{v}$. The results are shown in table 2 .

\section{Specificity}

The Specificity Studies are carried out by varying specific conditions i.e. Placebo study. Chromatogram of placebo doesn't show interference at the retention time of Clozapine. Therefore this method is specific for determination of Clozapine.

\section{Linearity}

From the Linearity data, it was observed that the method was showing linear in the concentration range of $10-60 \mu \mathrm{g} / \mathrm{ml}$ for Clozapine. The correlation coefficient was found to be 0.995 .

\section{Accuracy}

The recovery studies were performed. They found to be in the range of $98.38 \%-99.23 \%$, which shows that the method was accurate. The results are shown in table 3 .

\section{Precision}

The precision of the method was evaluated by carrying system precision, method precision, Intra-day and inter-day precision studies. The percentage relative standard deviation (\% RSD) of each study was calculated and was found to be less than $2 \%$ hence the method was found to be precise. The results are shown in table 4 .

\section{LOD and LOQ}

Limit of detection (LOD) and limit of quantitation (LOQ) of the method was found to be $2.7 \mu \mathrm{g} / \mathrm{ml}$ and $8.4 \mu \mathrm{g} / \mathrm{ml}$ respectively. Limit of detection (LOD) and limit of quantitation (LOQ) of the method was found to be $2.7 \mu \mathrm{g} / \mathrm{ml}$ and $8.4 \mu \mathrm{g} / \mathrm{ml}$ respectively.

\section{Robustness}

No significant change in the chromatographic parameters was observed when changing the optimized condition like a change in the flow rate and wavelength. The results are shown in table 5

\section{Ruggedness}

Comparison of the results obtained by two analyst's shows that the method is rugged for an analyst to analyst variability. The results are shown in table 6.

\section{System suitability}

All the values of system suitability were found to be within in the acceptable limits. It concluded that the method and systems are adequate for the analysis to be performed. The result of system suitability studies are shown in table 7.

\section{Stability studies}

The standard solution was exposed to water, acid $(0.1 \mathrm{~N} \mathrm{HCl})$, base $(0.1 \mathrm{~N} \mathrm{NaOH})$, an oxidizing agent $\left(3 \% \mathrm{H}_{2} \mathrm{O}_{2}\right)$, Heat, UV-Light, and water. Degradation of drug substances are between 5 to $20 \%$ has been accepted for validation of chromatographic assays. From the results, degradation of Clozapine was shown more in alkaline condition. The results are shown in table 8.

\section{Bioequivalence studies}

The percentage release of Clozapine formulations by dissolution was found to within the acceptable limits i.e., NLT $85 \%$ in $45 \mathrm{~min}$ as per USP. The results are shown in table 9.<smiles>CN1CCN(C2=Nc3cc(Cl)ccc3Nc3ccccc32)CC1</smiles>

Fig. 1: Structure of clozapine

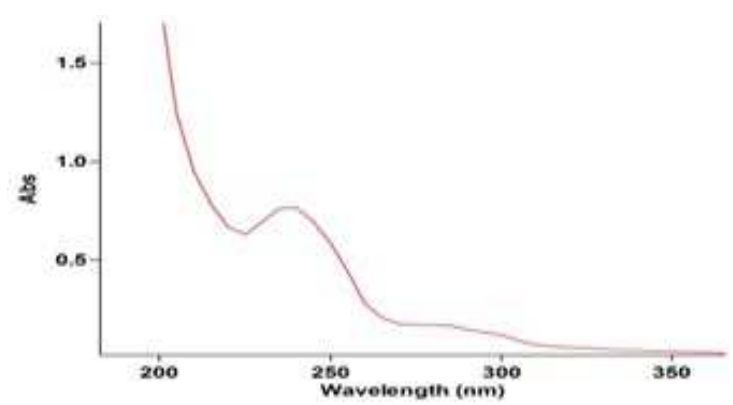

Fig. 2: UV spectrum of clozapine

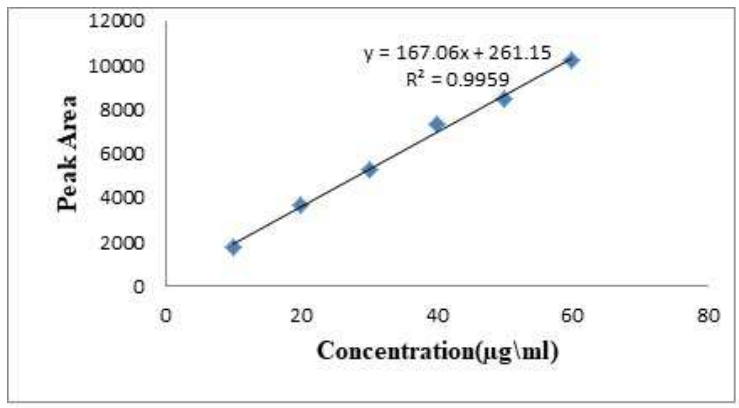

Fig. 3: Linearity plot for clozapine

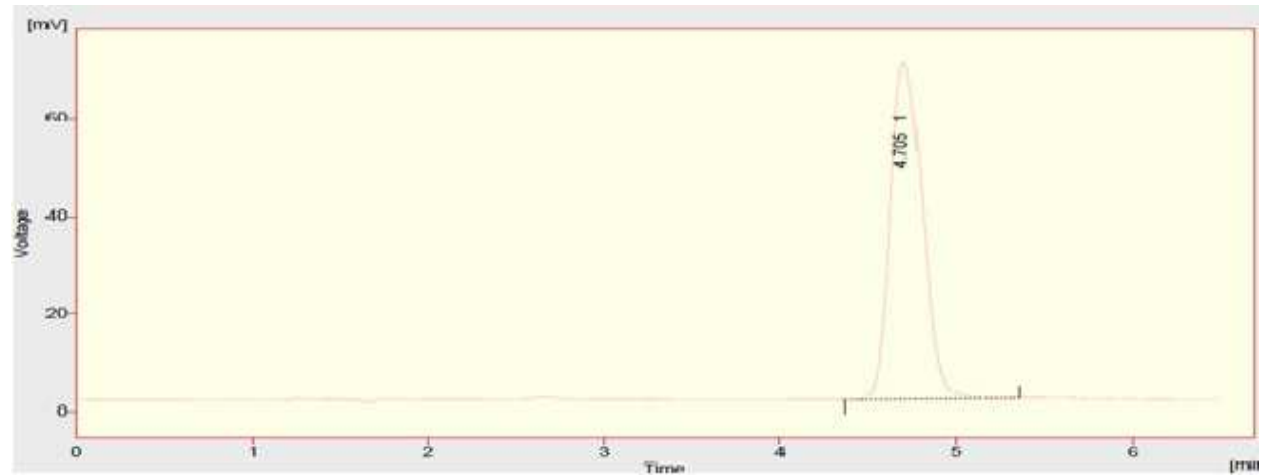

Fig. 4: HPLC chromatogram for standard 


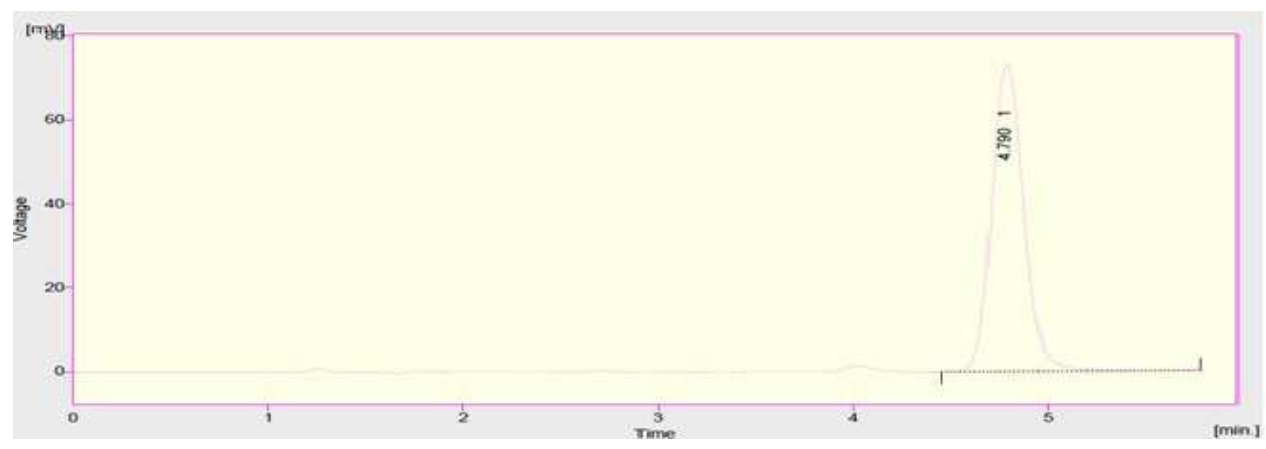

Fig. 5: HPLC chromatogram of a sample

Table 1: Optimized conditions for clozapine

\section{Parameter}

Column

Mobile Phase

Flow rate $(\mathrm{ml} / \mathrm{min})$

Column temperature $\left({ }^{\circ} \mathrm{C}\right)$

Injection volume $(\mu \mathrm{l})$

Detection wavelength $(\mathrm{nm})$

Drug RT (min)

Method
Phenomenex ODS $\mathrm{C}_{18}(150 \times 4.6 \mathrm{~mm}, 5 \mu)$
Methanol and Water $(80: 20)$
$1.0 \mathrm{ml} / \mathrm{min}$
$25^{\circ} \mathrm{C}$
$20 \mu \mathrm{l}$
$240 \mathrm{~nm}$
4.790

Table 2: Quantitative determination of clozapine

\begin{tabular}{llllll}
\hline S. No. & Formulation & Concentration $(\boldsymbol{\mu g} / \mathbf{m l})$ & Retention time & $\begin{array}{l}\text { Label } \\
\text { claim (mg) }\end{array}$ & $\begin{array}{l}\text { Amount } \\
\text { found (mg) }\end{array}$ \\
\hline 1 & Clopine (Clozapine) & 10 & 4.790 & 25 & 24.83 \\
\hline
\end{tabular}

Table 3: Recovery studies of clozapine

\begin{tabular}{|c|c|c|c|c|c|c|c|}
\hline S. No. & Recovery level & Sample concen. $(\mu \mathrm{g} / \mathrm{ml})$ & Amount spiked (ml) & $\%$ recovery & Average & SD & \% RSD \\
\hline 1 & $80 \%$ & 10 & 0.8 & 98.17 & & & \\
\hline 2 & $80 \%$ & 10 & 0.8 & 99.39 & 98.38 & 0.918 & 0.933 \\
\hline 3 & $80 \%$ & 10 & 0.8 & 97.59 & & & \\
\hline 4 & $100 \%$ & 10 & 1 & 98.10 & & & \\
\hline 5 & $100 \%$ & 10 & 1 & 94.73 & 98.21 & 1.458 & 1.485 \\
\hline 6 & $100 \%$ & 10 & 1 & 96.82 & & & \\
\hline 7 & $120 \%$ & 10 & 1.2 & 98.16 & & & \\
\hline 8 & $120 \%$ & 10 & 1.2 & 100.28 & 99.23 & 1.060 & 1.068 \\
\hline 9 & $120 \%$ & 10 & 1.2 & 99.25 & & & \\
\hline
\end{tabular}

Table 4: Precision data foe clozapine

\begin{tabular}{llll}
\hline S. No. & Precision & \% RSD & Acceptance Limit \\
\hline 1 & System Precision & 1.052 & NMT $2 \%$ \\
2 & Method Precision & 1.662 & NMT $2 \%$ \\
3 & Intraday Precision & 1.023 & NMT $2 \%$ \\
4 & Interday Precision & 0.930 & NMT $2 \%$ \\
\hline
\end{tabular}

Table 5: Robustness data for clozapine

\begin{tabular}{|c|c|c|c|c|c|c|}
\hline S. No. & Parameter & Modifications & Retention time & Peak area & Tailing factor & \% RSD \\
\hline \multirow[t]{3}{*}{1} & Flow rate $( \pm 0.1 \mathrm{ml} / \mathrm{min})$ & $0.9 \mathrm{ml} / \mathrm{min}$ & 4.907 & 2319.648 & 1.161 & 1.619 \\
\hline & & $1.0 \mathrm{ml} / \mathrm{min}$ & 4.701 & 2071.125 & 1.130 & 1.191 \\
\hline & & $1.1 \mathrm{ml} / \mathrm{min}$ & 4.026 & 1912.358 & 1.164 & 1.421 \\
\hline \multirow[t]{3}{*}{2} & Wavelength (nm) & 238.00 & 4.412 & 2058.057 & 1.093 & 1.300 \\
\hline & $( \pm 2 \mathrm{~nm})$ & 240.00 & 4.701 & 2071.125 & 1.130 & 1.191 \\
\hline & & 242.00 & 4.812 & 1591.185 & 1.415 & 1.052 \\
\hline
\end{tabular}

Table 6: Ruggedness data for clozapine

\begin{tabular}{llll}
\hline S. No. & Analysts & Retention time & Peak area \\
\hline \multirow{2}{*}{1} & & 4.700 & 2061.892 \\
& Analyst-1 & 4.713 & 2082.236 \\
\multirow{2}{*}{2} & & 4.703 & 2013.835 \\
& Analyst-2 & 4.758 & 2083.148 \\
& & 4.757 & 2058.260 \\
\hline
\end{tabular}


Table 7: System suitability data for clozapine

\begin{tabular}{llll}
\hline S. No. & Parameters & Values obtained & Acceptance criteria \\
\hline 1 & Plate count & 4567 & $\geq 2000$ \\
2 & Tailing factor & 1.205 & $\leq 2.0$ \\
3 & Retention time & 4.790 & \\
\hline
\end{tabular}

Table 8: Summary of the stability studies

\begin{tabular}{lllll}
\hline S. No. & Stress degradation & Stress condition & Time & Peak area \\
\hline 1 & Acidic & $0.1 \mathrm{~N} \mathrm{HCL}$ & $30 \mathrm{~min}$ & 1635.768 \\
2 & Alkaline & $0.1 \mathrm{~N} \mathrm{NaoH}$ & $30 \mathrm{~min}$ & 3239.679 \\
3 & Oxidative & $30 \% \mathrm{H}_{2} \mathrm{O}_{2}$ & $30 \mathrm{~min}$ & 1620.186 \\
4 & Thermal & $105{ }^{\circ} \mathrm{C}$ & $7 \mathrm{~h}$ & 1904.289 \\
5 & Photolytic & $\mathrm{UV} \mathrm{Chamber}$ & 7 days & 1141.810 \\
6 & Neutral & $\mathrm{H}_{2} \mathrm{O}$ & $30 \mathrm{~min}$ & 2486.083 \\
\hline
\end{tabular}

Table 9: Bioequivalence studies data

\begin{tabular}{lllll}
\hline S. No. & Brands & Retention time & Label claim $\mathbf{( m g} / \mathbf{m l})$ & Amount found (mg/ml) \\
\hline 1 & Sizopin & 1.55 & 25 & 25.036 \\
2 & Skizoril & 1.55 & 25 & 24.623 \\
3 & Clozaril & 1.55 & 25 & 24.880 \\
4 & Clomach & 1.55 & 25 & 24.778 \\
\hline
\end{tabular}

\section{CONCLUSION}

A simple, precise and accurate method was developed for the estimation of Clozapine by RP-HPLC technique. Bioequivalence studies and forced degradation studies were also performed using the optimized method. The sample preparation is simple and the analysis time is short. The analytical procedure is validated as per ICH Q2B guidelines and shown to be accurate, precise and specific. In vitro bioequivalence studies were performed based on the USP Pharmacopeia. The analytical method validation and bioequivalence studies of Clozapine by RP-HPLC method was found to be satisfactory and could be used for the quality control analysis and pharmacokinetic studies of Clozapine.

\section{ABBREVIATION}

RP-HPLC: Reverse phase-High performance liquid chromatography, ICH: International Conference on Harmonization, LOD: Limit of detection, LOQ: Limit of quantification, USP: The United States of Pharmacopeia, RSD: Relative standard deviation, CONCEN: Concentration,V. F: Volumetric flask.

\section{ACKNOWLEDGEMENT}

I would like to thank Arvind Remedies Pvt Ltd; we are highly thankful Dr. K. Ashok Kumar, Principal, Sree Vidyanikethan College of Pharmacy, Sree Sainath Nagar, Chandragiri (Mandal) Tirupati, Chittoor Dist, A. P for providing the necessary facilities to carry out this research work.

\section{CONFLICT OF INTERESTS}

The authors declare no conflicts of interest

\section{REFERENCES}

1. www.drugblank.com [Last accessed on 10 Dec 2017]
2. Kaur H, Bassi P, Monif T, Khuroo A, Kaur G. Development and validation of high performance liquid chromatographic method for analysis of clozapine. Pak J Pharm Sci 2013;26:465-72.

3. Uma A Patil, Bijaya Ghosh. Reverse phase liquid chromatographic method for the estimation of clozapine from tablet dosage forms. Int J PharmTech Res 2009;1:733-6.

4. Chokchai Wongsinsup, Wandee Taesotikul, Sayam Kaewvichit, Siriluk Sangsrijan, Saowarunee Sangsrijan. Determination of clozapine in human plasma by high-performance liquid chromatography with UV-VIS detector. CMU J Nat Sci 2010;9:29-37.

5. Emrah Dural, Gorkem Mergen, Tulin Soylemezoglu. Optimization and validation of an HPLC-UV method for analysis of clozapine and its major metabolites in human plasma. Turk J Pharm Sci 2015;12:177-86.

6. MA Raggi, F Bugamelli, R Mandrioli, D De Ronchi, V Volterra. Development and validation of an HPLC method for the simultaneous determination of clozapine and desmethylclozapine in plasma of schizophrenic patients. Chromatographia 1999;49:75-80.

7. ICH Harmonised Tripartite guidelines: validation of analytical procedures: text and methodology Q2(R1); 1996. p. 1-13.

8. ICH harmonized tripartite guideline stability testing. Photostability testing of new drug substances and products: Q1B Current Step 4 version dated 6 November; 1996.

9. Trivikram Rawat, IP Pandey. Forced degradation studies for drug substances and drug products-scientific and regulatory considerations. Int J Pharm Sci Res 2015;7:238-41.

10. MS Charde. Jitendra Kumar AS, Welankiwar R, D Chakole. Development of forced degradation studies of drugs. Int J Adv Pharm 2013;2:159-65. 